\title{
Front Matter: Volume 7975
}

, "Front Matter: Volume 7975," Proc. SPIE 7975, Bioinspiration, Biomimetics, and Bioreplication, 797501 (4 May 2011); doi: 10.1117/12.894738

Event: SPIE Smart Structures and Materials + Nondestructive Evaluation and Health Monitoring, 2011, San Diego, California, United States 


\title{
PROCEEDINGS OF SPIE
}

\section{Bioinspiration, Biomimetics, and Bioreplication}

\author{
Raúl J. Martín-Palma \\ Akhlesh Lakhtakia \\ Editors
}

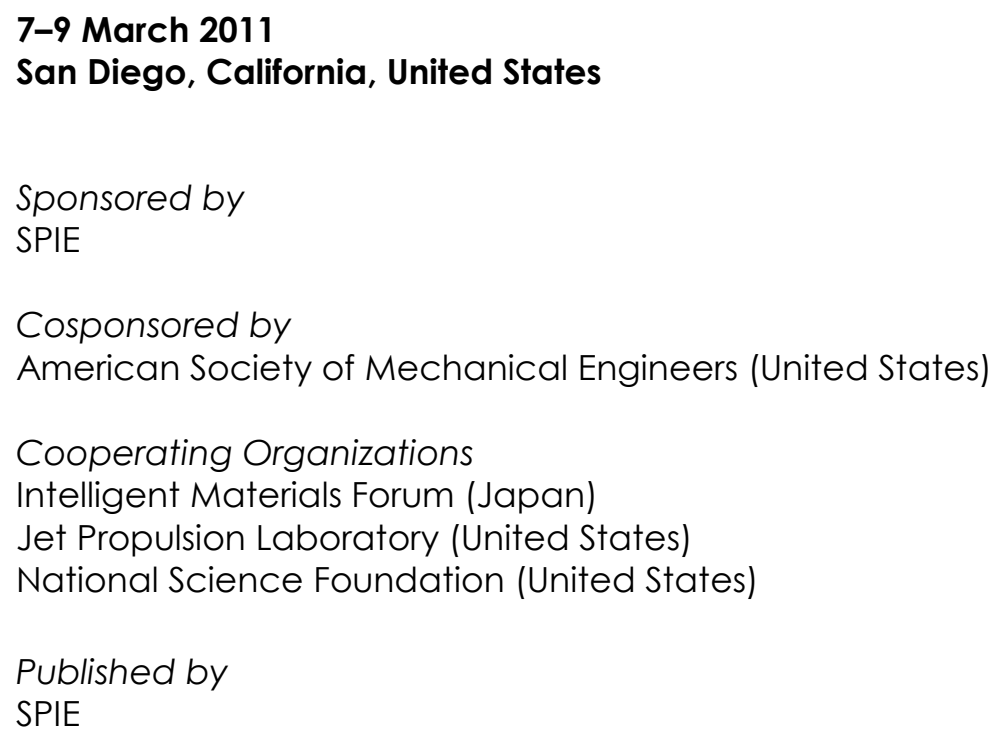


The papers included in this volume were part of the technical conference cited on the cover and title page. Papers were selected and subject to review by the editors and conference program committee. Some conference presentations may not be available for publication. The papers published in these proceedings reflect the work and thoughts of the authors and are published herein as submitted. The publisher is not responsible for the validity of the information or for any outcomes resulting from reliance thereon.

Please use the following format to cite material from this book:

Author(s), "Title of Paper," in Bioinspiration, Biomimetics, and Bioreplication, edited by Raúl J. Martín-Palma, Akhlesh Lakhtakia, Proceedings of SPIE Vol. 7975 (SPIE, Bellingham, WA, 2011) Article CID Number.

ISSN 0277-786X

ISBN 9780819485373

Published by

SPIE

P.O. Box 10, Bellingham, Washington 98227-0010 USA

Telephone +1 3606763290 (Pacific Time) · Fax +1 3606471445

SPIE.org

Copyright (C) 2011, Society of Photo-Optical Instrumentation Engineers

Copying of material in this book for internal or personal use, or for the internal or personal use of specific clients, beyond the fair use provisions granted by the U.S. Copyright Law is authorized by SPIE subject to payment of copying fees. The Transactional Reporting Service base fee for this volume is $\$ 18.00$ per article (or portion thereof), which should be paid directly to the Copyright Clearance Center (CCC), 222 Rosewood Drive, Danvers, MA 01923. Payment may also be made electronically through CCC Online at copyright.com. Other copying for republication, resale, advertising or promotion, or any form of systematic or multiple reproduction of any material in this book is prohibited except with permission in writing from the publisher. The CCC fee code is 0277-786X/11/ \$18.00.

Printed in the United States of America.

Publication of record for individual papers is online in the SPIE Digital Library.

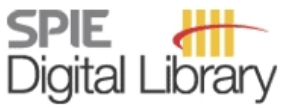

SPIEDigitalLibrary.org

Paper Numbering: Proceedings of SPIE follow an e-First publication model, with papers published first online and then in print and on CD-ROM. Papers are published as they are submitted and meet publication criteria. A unique, consistent, permanent citation identifier (CID) number is assigned to each article at the time of the first publication. Utilization of CIDs allows articles to be fully citable as soon they are published online, and connects the same identifier to all online, print, and electronic versions of the publication. SPIE uses a six-digit CID article numbering system in which:

- The first four digits correspond to the SPIE volume number.

- The last two digits indicate publication order within the volume using a Base 36 numbering system employing both numerals and letters. These two-number sets start with 00, 01, 02, 03, 04, $05,06,07,08,09,0 A, 0 B \ldots 0 Z$, followed by 10-1Z, 20-2Z, etc.

The CID number appears on each page of the manuscript. The complete citation is used on the first page, and an abbreviated version on subsequent pages. Numbers in the index correspond to the last two digits of the six-digit CID number. 


\section{Contents}

vii Conference Committee

\section{SESSION 1 SENSORS I}

797503 Bioinspired optical sensors for unmanned aerial systems (Invited Paper) [7975-02]

J. Chahl, K. Rosser, Defence Science and Technology Organisation (Australia); A. Mizutani, Odonatrix Pty Ltd. (Australia)

797505 Biomimetic gas sensors for large-scale drying of wood particles [7975-04]

S. Paczkowski, Univ. Göttingen (Germany); T. Saverwald, A. Weiß, M. Baver, D. Kohl, Univ. Giessen (Germany); S. Schütz, Univ. Göttingen (Germany)

\section{SESSION 2 SENSORS II}

797506 Biomimetic infrared sensors based on the infrared receptors of pyrophilous insects [7975-05] H. Schmitz, T. Kahl, Univ. Bonn (Germany); H. Soltner, H. Bousack, Forschungszentrum Jülich GmbH (Germany)

797507 Lateral line canal morphology and signal to noise ratio [7975-06]

A. Klein, H. Herzog, H. Bleckmann, Univ. of Bonn (Germany)

797508 Bioinspired vision sensors with hyperacuity [7975-07]

S. F. Barrett, C. H. G. Wright, Univ. of Wyoming (United States)

797509 Hair cell sensing with encapsulated interface bilayers [7975-08]

S. A. Sarles, D. J. Leo, Virginia Polytechnic Institute and State Univ. (United States)

\section{SESSION 3 MECHANICAL PROPERTIES}

7975 OA Chemical wave characterization of self-oscillating gelatin and polyacrylamide gels (Invited Paper) [7975-11]

M. L. Smith, Air Force Research Lab. (United States); K. Heitfeld, Renegade Materials (United States); M. Tchoul, R. A. Vaia, Air Force Research Lab. (United States)

7975 OB The importance of water for the mechanical properties of insect cuticle [7975-12]

D. Klocke, H. Schmitz, Univ. of Bonn (Germany)

7975 OC Bioinspired assembly of nanoplatelets for reinforced polymer nanocomposites [7975-13] W.-H. Huang, X. Dou, P. Jiang, Univ. of Florida (United States)

7975 OD Computational multi-scale constitutive model for wood cell wall and its application to the design of bio-inspired composites [7975-14]

E. I. Saavedra Flores, M. S. Murugan, M. I. Friswell, E. A. de Souza Neto, Swansea Univ. (United Kingdom) 
7975 OG Optics of spider "sticky" orb webs [7975-17]

D. M. Kane, G. R. Staib, N. Naidoo, D. J. Little, M. E. Herberstein, Macquarie Univ. (Australia)

$7975 \mathrm{OH} \quad$ Prismatic bioinspired compound lenses for solar cells [7975-18]

F. Chiadini, Univ. of Salerno (Italy); V. Fiumara, Univ. of Basilicata (Italy); A. Scaglione, Univ. of

Salerno (Italy); A. Lakhtakia, The Pennsylvania State Univ. (United States)

SESSION 5 FLIGHT

7975 OK Closed loop heading control in the tobacco hawkmoth, Manduca sexta [7975-21]

M. W. Shafer, R. Tiwari, E. Garcia, Cornell Univ. (United States)

7975 OL Two-dimensional localized flow control using distributed, biomimetic feather structures: a comparative study [7975-22]

C. J. Blower, A. M. Wickenheiser, The George Washington Univ. (United States)

7975 ON The barn owl wing: an inspiration for silent flight in the aviation industry? [7975-24]

T. Bachmann, Technische Univ. Darmstadt (Germany); G. Mühlenbruch, RWTH Aachen Univ. Hospital (Germany); H. Wagner, RWTH Aachen Univ. (Germany)

\section{SESSION 6 FABRICATION AND APPLICATIONS I}

$797500 \quad$ Engineered biomimicry: polymeric replication of surface features found on insects [7975-25] D. P. Pulsifer, A. Lakhtakia, The Pennsylvania State Univ. (United States); R. J. Martín-Palma, The Pennsylvania State Univ. (United States) and Univ. Autónoma de Madrid (Spain);

C. G. Pantano, The Pennsylvania State Univ. (United States)

7975 OP BOWOOSS: bionic optimized wood shells with sustainability [7975-26]

G. Pohl, Hochschule für Technik und Wirtschaft des Saarlandes (Germany)

$7975 \mathrm{OQ} \quad$ Modeling and optimization of IPMC actuator for autonomous jellyfish vehicle (AJV) [7975-27]

K. B. Joshi, Virginia Polytechnic Institute and State Univ. (United States); B. J. Akle, Virginia Polytechnic Institute and State Univ. (United States) and Lebanese American Univ. (Lebanon); D. J. Leo, S. Priya, Virginia Polytechnic Institute and State Univ. (United States)

7975 OR Bio-inspired hovering and locomotion via wirelessly powered ionic polymer metal composites [7975-28]

K. Abdelnour, Polytechnic Institute of New York Univ. (United States); A. Stinchcombe, New York Univ. (United States); M. Porfiri, Polytechnic Institute of New York Univ. (United States);

J. Zhang, S. Childress, New York Univ. (United States)

\section{SESSION 7 BIOMEDICAL APPLICATIONS}

7975 OU Acceleration of osteogenesis by using barium titanate piezoelectric ceramic as an implant material [7975-31]

K. Furuya, Y. Morita, K. Tanaka, T. Katayama, E. Nakamachi, Doshisha Univ. (Japan) 
7975 OV Single channel conductance modeling of the peptide alamethicin in synthetically formed bilayers [7975-32]

M. A. Creasy, D. J. Leo, Virginia Polytechnic Institute and State Univ. (United States)

7975 OW Snake oil and venoms for medical research [7975-33]

H. D. Wolpert, Bio-Optics (United States)

\section{SESSION 8 FABRICATION AND APPLICATIONS II}

7975 0X Directional control valve with the ability to "dangle" [7975-34]

M. Meller, R. Tiwari, E. Garcia, Cornell Univ. (United States)

7975 OY Biomimetic super-hydrophobic surfaces for use in enhanced dropwise condensation [7975-35]

K. Cheng, B. J. Zhang, C. Y. Lee, M. Kennedy, Univ. of Nevada, Reno (United States);

S. Kim, Univ. of Nevada, Reno (United States) and Univ. of Alaska, Fairbanks (United States);

$\mathrm{H}$. Yoon, Univ. of Nevada, Reno (United States) and Korea Institute of Energy Research

(Korea, Republic of); K. J. Kim, Univ. of Nevada, Reno (United States); J. Liu, G. Skandan,

NEl Corp. (United States)

$7975 \mathrm{OZ}$ Biomimetically tunable hydrophobic/hydrophilic surfaces: multiple tier roughness [7975-37]

B. J. Zhang, J. Park, C. Y. Lee, K. J. Kim, B. Belmont, Univ. of Nevada, Reno (United States)

POSTER SESSION

797510 Inspection and analysis of the walls of fluid filled tubes by active electrolocation: a biomimetic approach [7975-38]

M. Gottwald, K. Mayekar, V. Reiswich, Univ. Bonn (Germany); H. Bousack, D. Damalla,

S. Biswas, Forschungszentrum Jülich (Germany); M. G. Metzen, G. von der Emde, Univ. Bonn (Germany)

797514 Spitting cobras: fluid jets in nature as models for technical applications [7975-42]

A. Balmert, Univ. Bonn (Germany); D. Hess, C. Brücker, Technische Univ. Freiberg (Germany); H. Bleckmann, G. Westhoff, Univ. Bonn (Germany)

797517 Semiautomatic calibration and alignment of a low cost, 9 sensor inertial magnetic measurement sensor [7975-45]

A. Mizutani, Odonatrix Pty Ltd. (Australia); K. Rosser, J. Chahl, Defence Science and Technology Organisation (Australia)

797518 Vertically displaced optical flow sensors to control the landing of a UAV [7975-46]

J. Chahl, K. Rosser, Defence Science and Technology Organisation (Australia); A. Mizutani,

Odonatrix Pty Ltd. (Australia)

797519 Atomistic mechano-chemical modeling of kinesins [7975-47]

S. Patriche, RIKEN (Japan) and Univ. Dunarea de Jos of Galati (Romania); S. Matsushita, RIKEN (Japan) and Kyoto Univ. (Japan); M. Banu, Univ. Dunarea de Jos of Galati (Romania) and RIKEN (Japan); B. I. Epureanu, Univ. of Michigan, Ann Arbor (United States); T. Adachi, RIKEN (Japan) and Kyoto Univ. (Japan) 
79751 A Functional morphology of the adhesive organs of stick insects (Carausius morosus) [7975-48]

M. Bennemann, RWTH Aachen (Germany); I. Scholz, Rheinische Friedrich-Wilhelms-Univ. Bonn (Germany); W. Baumgartner, RWTH Aachen (Germany)

7975 1B Sandfish inspires engineering [7975-49]

K. Staudt, RWTH Aachen Univ. (Germany); F. Saxe, Max Planck Institute of Colloids and Interfaces (Germany); H. Schmied, Rheinische Friedrich-Wilhelms-Univ. Bonn (Germany); W. Böhme, Zoologisches Forschungsmuseum Alexander Koenig (Germany);

W. Baumgartner, RWTH Aachen Univ. (Germany)

Author Index 


\title{
Conference Committee
}

\author{
Symposium Chairs
}

Donald J. Leo, Virginia Polytechnic Institute and State University (United States)

Kara J. Peters, North Carolina State University (United States)

Symposium Cochairs

Norbert G. Meyendorf, Fraunhofer-Institut für Zerstörungsfreie

Prüfverfahren (Germany) and University of Dayton (United States)

Norman M. Wereley, University of Maryland, College Park (United

States)

Conference Chair

Raúl J. Martín-Palma, Universidad Autónoma de Madrid (Spain)

Conference Cochair

Akhlesh Lakhtakia, The Pennsylvania State University (United States)

Program Committee

Yoseph Bar-Cohen, Jet Propulsion Laboratory (United States)

Michael H. Bartl, The University of Utah (United States)

Frank E. Fish, West Chester University of Pennsylvania (United States)

Joshua L. Hertz, University of Delaware (United States)

Shuichi Kinoshita, Graduate School of Frontier Biosciences (Japan)

Sunghoon Kwon, Seoul National University (Korea, Republic of)

Torben A. Lenau, Technical University of Denmark (Denmark)

Radislav A. Potyrailo, GE Global Research (United States)

Mehmet Sarikaya, University of Washington (United States)

Jean-Pol Vigneron, Facultés Universitaires Notre-Dame de la Paix (Belgium)

James D. Weiland, The University of Southern California (United States)

H. Donald Wolpert, Bio-Optics (United States)

Session Chairs

1 Sensors I

Raúl J. Martín-Palma, Universidad Autónoma de Madrid (Spain) 
2 Sensors II

Joshua L. Hertz, University of Delaware (United States)

3 Mechanical Properties

Radislav A. Potyrailo, GE Global Research (United States)

4 Optics

H. Donald Wolpert, Bio-Optics (United States)

$5 \quad$ Flight

Raúl J. Martín-Palma, Universidad Autónoma de Madrid (Spain)

6 Fabrication and Applications I

Javaan Chahl, Defence Science and Technology Organisation (Australia)

$7 \quad$ Biomedical Applications

Akhlesh Lakhtakia, The Pennsylvania State University (United States)

8 Fabrication and Applications II

Akhlesh Lakhtakia, The Pennsylvania State University (United States) 